$\xi=$

\title{
Assessing composition and diversity of woody vegetation in mined arid and semi arid lands of Kerio valley, Kenya
}

\author{
Barsosio K Abraham *, Kirui K Bernard, Maara T Nelson \\ Egerton University, Department of Natural Resources \\ *Corresponding author E-mail: sukutek@gmail.com
}

\begin{abstract}
The woody vegetation in semi-arid area is important in providing ecosystem services and goods. However, it faces threats manifested in land-use changes such as mining. This study aimed at assessing the composition and diversity of woody vegetation as well as inherent soil physico-chemical parameters in a previously mined area and comparing it with a semi-pristine adjacent area. Six transects containing five plots each were established within two blocks separated by a river. In each plot, data was collected on woody tree growth characteristics and soil parameters. Thirteen woody species were recorded in the rehabilitated mined and twenty two in semi-pristine sites with Ficus sycomorus L Moraceae being the dominant species at the two sites. Woody vegetation diversity was higher in semi-pristine site than in the rehabilitated mined site. However, this was not significant (t-test, $=\mathrm{D} . \mathrm{F}=1 \mathrm{P}=0.767)$. Mean soil nutrients $\left(\mathrm{F}_{2},{ }_{7} .=\mathrm{P}=0.821\right)$, $\mathrm{pH}\left(\mathrm{F}_{2}, 7_{.}=109.88, \mathrm{P}=\mathrm{xxx}\right)$, was higher in rehabilitated mined sites while mean soil temperature $\left(\mathrm{F}_{2},{ }_{7} .=9.08, \mathrm{P}=0.011\right)$ was higher in mined areas. Rehabilitating mined sites can bring back species diversity, composition, however what is not clear is whether ecosystem functions are restored.
\end{abstract}

Keywords: Composition; Diversity; Mined; Rehabilitated; Woody Vegetation.

\section{Introduction}

Semi-arid environments are areas that receive annual rainfall of between $300-500 \mathrm{~mm}$ and they account for $18.8 \%$ of the total land area of the world and are diverse in their soils, fauna, flora, land forms, human activities and water balance (UNEP, 2006). Much of the water it receives from precipitation is lost through evapotranspiration and the vegetation cover is sparse and woody species is low (Thom, 1983). In Africa, they accounts for $46.1 \%$ of the total area while in Kenya it covers $80 \%$ of the total area (UNEP, 2006).

The deciduous woodland occurs throughout the Kenya ASALs and is dominated by Acacia tortilis with other notable species being Hyphaene ventricosa, Salvadora persica, Acacia nubica on the Northwest and northern Kenya and Commiphora and Acacias in the southern parts. (Kigomo, 2001). These areas provide support to about $30 \%$ of the total population in Kenya with the main economic activities being pastrolism and agro-pastrolism (Nangulu, 2001).

The Kerio valley is rich in minerals especially flourites used to manufacture ornamentals. As a result large areas of the valley have been exposed through activities of mining, leading to loss of vegetation. Extensive areas have been cleared of vegetation to create areas where mining activities are carried out. This has had devastating effects on landscapes leading to unavailability of vegetation for livestock, bio-fuel sources and sources of herbal medicine. Mining has led to changes in soil composition leading to difficulties in vegetation re-establishment.
Assessing distribution and composition of woody vegetation is important in informing plans on their harvesting and conservation (Newton, 2008) as well as providing information on their ecological status and resilience to disturbances caused by human or natural pressures (Omambia et al., 2009). Mining activities have been noted as key driver in microbiological changes in soil properties (Ghose et al., 2004). Comparing soil characteristics in rehabilitated and undisturbed mining sites is key in identifying appropriate soil and woody vegetation conservation measures. This study aimed at assessing the composition and diversity of woody vegetation as well as inherent soil physico-chemical parameters in a previously mined area and comparing it with a semi-pristine adjacent area. The findings are useful to natural resources managers as well as development partners in informing appropriate rehabilitation and management approaches in woody vegetation.

\section{Materials and methods}

\subsection{Study area}

This study was carried out in Kerio Valley $\left(0^{\circ} 19^{\prime} 0^{\prime \prime}\right.$ North, $35^{\circ}$ $\left.38^{\prime} 0^{\prime \prime}\right)$ located in Rift Valley, Kenya. The Kerio valley borders Elgeyo escarpment to the West and Tugen hills to the East. It is classified as semi-arid area in ecological zone V. The average annual temperature at the valley is $24^{\circ} \mathrm{C}$ and it receives a mean annual rainfall of below $1000 \mathrm{~mm}$. The study area is primarily alluvial plain with varying soils ranging from black-dark cotton soil, and four fluorite rich soils to fine textured soils covered with acacia woodland and scattered shrubs and woody vegetation comprising of Acacia tortilis and Acacia seyal. 


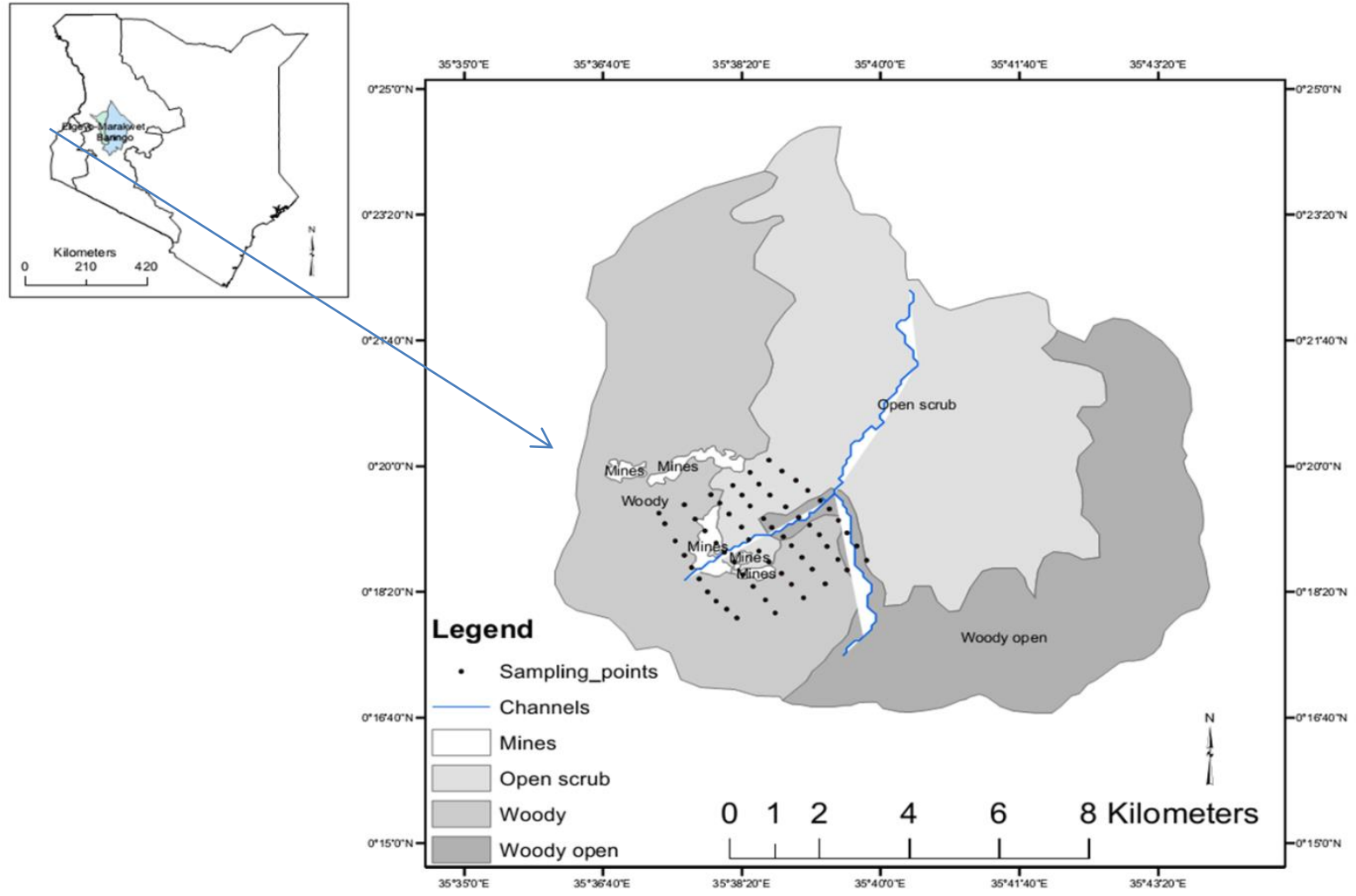

Fig. 1: Map of the Study Area.

\subsection{Research design}

To determine abundance and composition of woody vegetation and to compare the disturbed and undisturbed sites within the study area, random block design was used with six transects (three each) established between two blocks separated by River Kerio (Figure 1). At each side of the river, transects were established perpendicularly to the river shore. In each transect 5 plots measuring $20 \mathrm{~m}$ by $20 \mathrm{~m}$. The distance between plots in each transect was 50 meters. A number of these plots felt between areas where mining activities were conducted previously and provided an opportunity to compare growth characteristics with those in the undisturbed area.

\subsubsection{Assessment of abundance and composition}

Within the $20 \mathrm{~m}$ by $20 \mathrm{~m}$ plots established, data on the following parameters were collected; total counts per species, tree height, Diameter at Breast Height (DBH), Basal area, total woody vegetation counts, tree form and regeneration. Subplots measuring $5 \mathrm{~m}$ by $5 \mathrm{~m}$ and $1 \mathrm{~m}$ by $1 \mathrm{~m}$ was established within the plots for counting of sapling $(<10 \mathrm{~cm} \mathrm{DBH},>1.3 \mathrm{~m}$ Height $)$ and seedlings $(<10 \mathrm{~cm} \mathrm{DBH}$, $<1.3 \mathrm{~m}$ Height) for regenerations.

\subsubsection{Species richness and diversity}

Simpsons diversity index (excel) was used to compute diversity index of species between the two sites as follows;

$\mathrm{D}=1-\left(\sum \mathrm{n}(\mathrm{n}-1) / \mathrm{N}(\mathrm{N}-1)\right)$

Where;

$\mathrm{D}=$ Diversity index

$\mathrm{n}>$ the total number of trees of a particular species

$\mathrm{N}=$ the total number of trees of all species

To calculate species richness, Menhnick's index was used $\mathrm{D}=\mathrm{s} / \sqrt{\mathrm{N}}$

Where; s-number of different species

$\mathrm{N}$ - Total no. of individual species

\subsubsection{Soil characteristics}

Surface scrapes (to $1 \mathrm{~cm}$ depth) were taken for nutrient analysis. Surface temperature (thermometer probe inserted to $1 \mathrm{~cm}$ below sediment surface) was measured at midday on a clear sunny day. Sediments for nutrient analysis were collected in the field and preserved in an ice box before being taken to the laboratory. Lab nutrient extraction was done using potassium chloride flushed with nitrogen gas ( $2 \mathrm{~min}$ ) and shaken for $2 \mathrm{~h}$, to ensure maximum extraction. The samples were then centrifuged at a speed of 2000 rotations per minute for $10 \mathrm{~min}$. The extract was decanted and diluted with distilled water and used for the determination of nutrients. Soil nutrients was determined according to (Parsons 1984)

\subsection{Data analysis}

Summary of data analysis is provided in Table 3. Analysis was carried out using Minitab and Excel. Data was then cleaned and tested for normality and homogeneity of variance and transformed where these assumptions were not met. Descriptive and inferential statistics were used.

\section{Results}

\subsection{Species description at the two sites}

Analysis of characteristics of woody vegetation is summarized in table 4 below. There were Thirteen woody vegetation species encountered in the rehabilitated mined sites with Ficus sycomorus being the dominant species $(22.1 \%)$ followed by Tamarindus indica $(21.8 \%)$. Teclea nobilis was the least observed species (1.0\%). At the undisturbed sites, twenty two different species were encountered with Ficus sycomorus being dominant (15.5\%) followed by Cordia africana (12.1\%) and Euclea divinorum being the least observed $(0.7 \%)$.

Trees in the rehabilitated mined site had the lowest mean height $(8.2 \pm 0.4 \mathrm{~m})$ with individual tree heights ranging from $5.0 \mathrm{~m}$ for Euclea divinorum to $11.8 \mathrm{~m}$ for Ficus sycomorus. The highest mean height recorded at the undisturbed site was $8.8 \pm 0.7 \mathrm{~m}$ with 
individual tree heights ranging from $2.0 \mathrm{~m}$ (U. scheffleri) to $17.0 \mathrm{~m}$ (S. siamea) (Tables 4 and 5). Rehabilitated mined site had the highest basal area of $\left(644.0 \mathrm{~cm}^{2} / \mathrm{plot}\right)$ with F. sycomorus species having the highest mean basal area $\left(\left(1854.1 \pm 29.3 \mathrm{~cm}^{2} / \mathrm{plot}\right)\right.$ followed by $\mathrm{T}$. indica species $\left(1823.7 \pm 28.93 \mathrm{~cm}^{2} / \mathrm{plot}\right)$ and $\mathrm{T}$. nobilis species with the lowest basal area $\left(85.7 \pm 19.9 \mathrm{~cm}^{2} / \mathrm{plot}\right)$. In the undisturbed site the basal area was $472.2 \mathrm{~cm}^{2} /$ plot, with F. sycomorus recording the highest basal area $\left(1610.9 \pm 28.4 \mathrm{~cm}^{2} / \mathrm{plot}\right)$ followed by Cordia africana $\left(1260.2 \pm 23.6 \mathrm{~cm}^{2} / \mathrm{plot}\right)$. Euclea divinorum $\left(80.1 \pm 16.7 \mathrm{~cm}^{2} /\right.$ plot $)$ had the lowest basal area at this site.

Based on Importance Values (IV), A. tortilis was dominant species in both sites with an IV of 67.2 and 31.5 in rehabilitated mined and undisturbed site respectively. T. nobilis had the lowest IV in rehabilitated mined site with an importance value of 5.5 while P. vilidiflorum, U. scheffleri, V. madagascariensis species individually with an importance value of 3.0 being the least dominant in the undisturbed site. Complexity index was at a low of 22 in rehabilitated site and a high of 50 in the undisturbed site.

There was no significant difference in woody vegetation diversity between the two sites ( $T$-test $=\mathrm{D} . \mathrm{F}=1 \mathrm{P}=0.767$ ). Woody vegetation diversity was higher in undisturbed site than in the rehabilitated mined site (Table 4). In the undisturbed site cedar, Dodonea viscosa, Pittosporum vilidiflorum, Uvaria scheffleri and vanguera madagascariensis recorded the highest species richness (SR) of 21.0 each whereas Acacia tortilis had the lowest recording of species richness of 5.8 (table 4). In the rehabilitated mined site Acacia elatior, Ficus sycomorus and Teclea nobilis recorded the highest species richness of 9.2 each while Acacia tortilis had the lowest species richness of 2.5 (Table 4).

\subsection{Description of form tree woody stem}

Woody stem is used as an indicator of natural and anthropogenic pressures prevalent in a stand where straight woody stems are indicative of prevalent growth and development conditions (Hall, 1994). A qualitative approach of classifying woody stems is based on categories referred to as stem form, where a straight form is classified as form 1 and the least straight woody stem classified as form 3 (Hall, 1994). At the study area, the undisturbed sites had the highest number of all the quality class Form 1, 2 and $3(22,29$ and 45 poles $/ 0.4$ ha or $22.9 \%, 30.2 \%$ and $46.9 \%$ ) respectively whereas the rehabilitated sites had slightly lower distribution of the form 1,2 and 3 (20, 27 and 42 poles/0.4ha or $22.5 \%, 30.3 \%$ and $47.2 \%$ ) respectively. However Form 1 contributed the least proportion of stems in both undisturbed and rehabilitated mined sites at $22.9 \%$ and $22.5 \%$ respectively, while form 3 had the highest proportion (46.9\% and $47.2 \%$ ) respectively (Figure 2 ).
The mean number of seedlings in the undisturbed site $(8 \pm 2.8)$ was higher as compared to the mean of seedlings in the rehabilitated mined site $(5.9 \pm 2.5)$, while the mean distribution of saplings was higher in rehabilitated mined area $(12.1 \pm 3.0)$ whereas the undisturbed site $8.6 \pm 2.8$ recorded a lower mean.

\subsection{Number of cut stumps at the two sites}

Cut stumps are an indicator of the anthropogenic pressures prevalent at a site. The highest number of cut stumps were recorded in the undisturbed site (1072 stumps or 53.2\%) and rehabilitated site (942 stumps or 46.8\%) the lowest (Figure 4).

\subsection{Soil characteristics at the two sites}

There was significant difference in the mean soil temperature, $\mathrm{pH}$, nitrogen, organic carbon, phosphorous, potassium and calcium between the three sites $\left(\mathrm{F}_{2}, 7_{7}=9.08, \mathrm{P}=0.011, \mathrm{~F}_{2}, 7_{7}=109.88\right.$, $\mathrm{P}<0.01, \mathrm{~F}_{2}, 7_{\text {. }}=22.47, \mathrm{P}=0.001, \mathrm{~F}_{2}, 7_{7}=29.93, \mathrm{P}<0.01, \mathrm{~F}_{2},{ }_{7} .=295.2$, $\mathrm{P}=0.005, \mathrm{~F}_{2},{ }_{7} .=53.97, \mathrm{P}<0.001$ and $\left.\mathrm{F}_{2}, 7 .=50.7, \mathrm{P}<0.001\right)$ respectively. Soil temperature in the recently mined sites was significantly higher than the other two sites (Figure 5a). Soil $\mathrm{pH}$ in recently mined site was significantly higher than in the other two sites (Figure 5b). Amounts of soil nitrogen were significantly high in rehabilitated mined site than the other two sites (Figure 5c). Soil organic carbon was significantly higher in rehabilitated mined site than in the other two sites (Figure 5d). Soil phosphorous in rehabilitated mined site was significantly higher than in the other two sites (Figure 5e). Soil potassium was significantly higher in the recently mined site than in the other two sites (Figure 5f). Soil calcium was significantly higher in rehabilitated mined site than in the other two sites (Figure $5 \mathrm{~g}$ ).

There was significant difference in soil magnesium, manganese, copper, iron, zinc and sodium between the three sites $\left(F_{2}, 7\right.$. $=50.58, \mathrm{P}<0.001, \mathrm{~F}_{2}, 7 .=27.36, \mathrm{P}<0.001, \mathrm{~F}_{2}, 7_{.}=141.17, \mathrm{P}<0.001$, $\mathrm{F}_{2}, 7_{7}=7.91, \mathrm{P}=0.016, \mathrm{~F}_{2}, 7_{7}=5.15, \mathrm{P}=0.042$ and $\mathrm{F}_{2},{ }_{7} .=7.86$, $\mathrm{P}=0.016$ ) respectively. However Soil magnesium was significantly higher in rehabilitated mined site than in the other two sites (Figure 5). Soil manganese was significantly higher in rehabilitated mined site than in the other two sites (Figure 5). Soil copper was significantly higher in recently mined site than in the other two sites. Soil iron in recently mined site was significantly higher than in the other two sites (Figure 5k). Soil zinc was significantly high in recently mined site than in the other two sites. Soil sodium was significantly high in undisturbed site than in the other two sites (Figure 5).

\subsection{Status regeneration of saplings and seedlings}

Table 4: Abundance and Composition of Woody Vegetation in Rehabilitated Mined Site and Undisturbed Site

\begin{tabular}{|c|c|c|c|c|c|c|c|c|c|c|c|}
\hline $\begin{array}{l}\text { Species } \\
\text { Rehabilitated } \\
\text { mined site }\end{array}$ & $\begin{array}{l}\text { No. of } \\
\text { species }\end{array}$ & $\begin{array}{l}\text { Mean } \\
\mathrm{DBH} \pm \mathrm{SE}\end{array}$ & $\begin{array}{l}\text { Mean Tree } \\
\mathrm{Ht} \pm \mathrm{SE}\end{array}$ & $\begin{array}{l}\text { Basal area } \\
\left(\mathrm{m}^{2} / \text { plot }\right) \pm \mathrm{SE}\end{array}$ & $\begin{array}{l}\text { Species } \\
\text { Diversity }\end{array}$ & $\begin{array}{l}\text { Species } \\
\text { Richness }\end{array}$ & $\begin{array}{l}\text { Relative Fre- } \\
\text { quency }(\%)\end{array}$ & $\begin{array}{l}\text { Relative } \\
\text { density \%) }\end{array}$ & $\begin{array}{l}\text { Relative } \\
\text { dominance \%) }\end{array}$ & $\begin{array}{l}\text { I. } \\
\text { V }\end{array}$ & $\begin{array}{l}\mathrm{C} \\
. \mathrm{I}\end{array}$ \\
\hline A. elatior & 2 & $33.2 \pm 2.3$ & $7.7 \pm 0.6$ & $865.3 \pm 12.5$ & & 9.2 & 2.2 & 2.2 & 10.3 & $\begin{array}{l}14 \\
.8\end{array}$ & $\begin{array}{l}2 \\
2\end{array}$ \\
\hline A. seyal & 11 & $26.9 \pm 3.8$ & $9.2 \pm 0.8$ & $569.2 \pm 7.3$ & & 3.9 & 12.4 & 12.4 & 6.8 & $\begin{array}{l}31 \\
.5\end{array}$ & \\
\hline A. tortilis & 27 & $26.5 \pm 0.8$ & $9.6 \pm 1.0$ & $550.5 \pm 8.1$ & & 2.5 & 30.3 & 30.3 & 6.6 & $\begin{array}{l}67 \\
.2\end{array}$ & \\
\hline A.schimperi & 6 & $13.5 \pm 2.9$ & $5.8 \pm 1.3$ & $142.4 \pm 18.8$ & & 5.3 & 6.7 & 6.7 & 1.7 & $\begin{array}{l}15 \\
.2\end{array}$ & \\
\hline B.aegyptica & 11 & $32.0 \pm 2.1$ & $9.4 \pm 0.9$ & $805.2 \pm 10.7$ & & 3.9 & 12.4 & 12.4 & 9.6 & $\begin{array}{l}34 \\
.3\end{array}$ & \\
\hline C.farinose & 3 & $11.4 \pm 3.2$ & $5.8 \pm 1.3$ & $102.0 \pm 19.6$ & & 7.5 & 3.4 & 3.4 & 1.2 & $\begin{array}{l}8 . \\
0\end{array}$ & \\
\hline E.divinorum & 4 & $11.9 \pm 3.1$ & $5.0 \pm 1.5$ & $110.2 \pm 19.4$ & & 6.5 & 4.5 & 4.5 & 1.3 & $\begin{array}{l}10 \\
.3\end{array}$ & \\
\hline Fi.sycomorus & 2 & $48.6 \pm 4.0$ & $11.8 \pm 1.6$ & $1854.1 \pm 29.3$ & & 9.2 & 2.2 & 2.2 & 22.1 & $\begin{array}{l}26 \\
.6\end{array}$ & \\
\hline S.siamea & 6 & $27.9 \pm 1.3$ & $11 \pm 1.4$ & $612.5 \pm 4.7$ & & 5.3 & 6.7 & 6.7 & 7.3 & $\begin{array}{l}20 \\
.8\end{array}$ & \\
\hline T.indica & 3 & $48.2 \pm 4.0$ & $8.7 \pm 0.6$ & $1823.7 \pm 28.9$ & & 7.5 & 3.4 & 3.4 & 21.8 & $\begin{array}{l}28 \\
.5\end{array}$ & \\
\hline
\end{tabular}




\begin{tabular}{|c|c|c|c|c|c|c|c|c|c|c|c|}
\hline T. nobilis & 2 & $10.5 \pm 3.3$ & $6.5 \pm 1.1$ & $85.7 \pm 19.9$ & & 9.2 & 2.2 & 2.2 & 1.0 & $\begin{array}{l}5 . \\
5\end{array}$ & \\
\hline Te. Brownie & 8 & $30.3 \pm 1.8$ & $9.0 \pm 0.8$ & $722.5 \pm 7.4$ & & 4.6 & 9.0 & 9.0 & 8.6 & $\begin{array}{l}26 \\
.6\end{array}$ & \\
\hline U. scheffleri & 4 & $12.8 \pm 3.0$ & $7.3 \pm 0.8$ & $128.6 \pm 19.1$ & 0.86 & 6.5 & 4.5 & 4.5 & 1.5 & $\begin{array}{l}10 \\
.5\end{array}$ & \\
\hline \multicolumn{12}{|l|}{$\begin{array}{l}\text { Undisturbed } \\
\text { site }\end{array}$} \\
\hline Acacia elatior & 3 & $14.8 \pm 2.3$ & $6.0 \pm 1.4$ & $172.7 \pm 14.6$ & & 12.1 & 3.1 & 3.1 & 1.7 & $\begin{array}{l}7 . \\
9\end{array}$ & $\begin{array}{l}5 \\
0\end{array}$ \\
\hline Acacia seyal & 8 & $27.5 \pm 2.0$ & $8.8 \pm 0.1$ & $593.12 \pm 9.2$ & & 7.4 & 8.3 & 8.3 & 5.7 & $\begin{array}{l}22 \\
.4\end{array}$ & \\
\hline Acacia tortilis & 13 & $24.2 \pm 2.5$ & $6.8 \pm 1.2$ & $459.7 \pm 3.0$ & & 5.8 & 13.5 & 13.5 & 4.4 & $\begin{array}{l}31 \\
.5\end{array}$ & \\
\hline A.schimperi & 9 & $13.6 \pm 2.5$ & $6.7 \pm 1.2$ & $145.2 \pm 15.2$ & & 7.0 & 9.4 & 9.4 & 1.4 & $\begin{array}{l}20 \\
.1\end{array}$ & \\
\hline B. aegyptica & 9 & $33.4 \pm 2.8$ & $9.8 \pm 0.8$ & $876.88 \pm 16.9$ & & 7.0 & 9.4 & 9.4 & 8.4 & $\begin{array}{l}27 \\
.2\end{array}$ & \\
\hline Cedar & 1 & $31.4 \pm 2.6$ & $8.3 \pm 0.6$ & $774.0 \pm 14.6$ & & 21.0 & 1.0 & 1.0 & 7.5 & $\begin{array}{l}9 . \\
5\end{array}$ & \\
\hline C. Africana & 3 & $40.1 \pm 3.6$ & $12.4 \pm 1.6$ & $1260.2 \pm 23.6$ & & 12.1 & 3.1 & 3.1 & 12.1 & $\begin{array}{l}18 \\
.4\end{array}$ & \\
\hline D.viscosa & 1 & $13.1 \pm 2.5$ & $6.7 \pm 1.2$ & $134.7 \pm 15.4$ & & 21.0 & 1.0 & 1.0 & 1.3 & $\begin{array}{l}3 . \\
4\end{array}$ & \\
\hline E. divinorum & 2 & $10.1 \pm 2.9$ & $5.5 \pm 1.5$ & $80.1 \pm 16.7$ & & 14.8 & 2.1 & 2.1 & 0.8 & $\begin{array}{l}4 . \\
9\end{array}$ & \\
\hline F. sycomorus & 3 & $45.3 \pm 4.1$ & $10.4 \pm 1.1$ & $1610.9 \pm 28.4$ & & 12.1 & 3.1 & 3.1 & 15.5 & $\begin{array}{l}21 \\
.8\end{array}$ & \\
\hline L. glauca & 2 & $16.5 \pm 2.0$ & $14.8 \pm 2.0$ & $213.7 \pm 13.5$ & & 14.8 & 2.1 & 2.1 & 2.1 & $\begin{array}{l}6 . \\
2\end{array}$ & \\
\hline M. lutea & 5 & $15.0 \pm 2.2$ & $16.5 \pm 2.3$ & $177.6 \pm 14.4$ & & 9.4 & 5.2 & 5.2 & 1.7 & $\begin{array}{l}12 \\
.1\end{array}$ & \\
\hline P. vilidiflorum & 1 & $11.2 \pm 2.8$ & $16.0 \pm 2.3$ & $98.5 \pm 16.3$ & & 21.0 & 1.0 & 1.0 & 0.9 & $\begin{array}{l}3 . \\
0\end{array}$ & \\
\hline O. europaea & 5 & $12.9 \pm 2.5$ & $5.8 \pm 1.5$ & $131.1 \pm 15.5$ & & 9.4 & 5.2 & 5.2 & 1.3 & $\begin{array}{l}11 \\
.7\end{array}$ & \\
\hline S. siamea & 5 & $23.4 \pm 1.0$ & $17.0 \pm 2.4$ & $429.1 \pm 5.5$ & & 9.4 & 5.2 & 5.2 & 4.1 & $\begin{array}{l}14 \\
.5\end{array}$ & \\
\hline T.indica & 4 & $35.4 \pm 3.1$ & $11.1 \pm 1.3$ & $985.1 \pm 19.0$ & & 10.5 & 4.2 & 4.2 & 9.5 & $\begin{array}{l}17 \\
.8\end{array}$ & \\
\hline T.brownie & 6 & $33.2 \pm 2.8$ & $8.3 \pm 0.6$ & $867.0 \pm 16.7$ & & 8.6 & 6.3 & 6.3 & 8.3 & $\begin{array}{l}20 \\
.8\end{array}$ & \\
\hline T. nobilis & 7 & $12.3 \pm 2.6$ & $4.9 \pm 1.7$ & $118.1 \pm 15.8$ & & 7.9 & 7.3 & 7.3 & 1.1 & $\begin{array}{l}15 \\
.7\end{array}$ & \\
\hline T. brownie & 5 & $32.1 \pm 2.7$ & $7.8 \pm 0.8$ & $808.9 \pm 15.4$ & & 9.4 & 5.2 & 5.2 & 7.8 & $\begin{array}{l}18 \\
.2\end{array}$ & \\
\hline T. camphoratus & 2 & $18.1 \pm 1.7$ & $4.5 \pm 1.8$ & $257.2 \pm 12.3$ & & 14.8 & 2.1 & 2.1 & 2.5 & $\begin{array}{l}6 . \\
6\end{array}$ & \\
\hline U. scheffleri & 1 & $11.0 \pm 2.8$ & $2.0 \pm 2.2$ & $95.0 \pm 16.3$ & & 21.0 & 1.0 & 1.0 & 0.9 & $\begin{array}{l}3 . \\
0\end{array}$ & \\
\hline $\begin{array}{l}\text { V.madagascari } \\
\text { ensis }\end{array}$ & 1 & $11.3 \pm 2.8$ & $4.3 \pm 1.8$ & $100.2 \pm 16.2$ & 0.93 & 21.0 & 1.0 & 1.0 & 1.0 & $\begin{array}{l}3 . \\
0\end{array}$ & \\
\hline
\end{tabular}

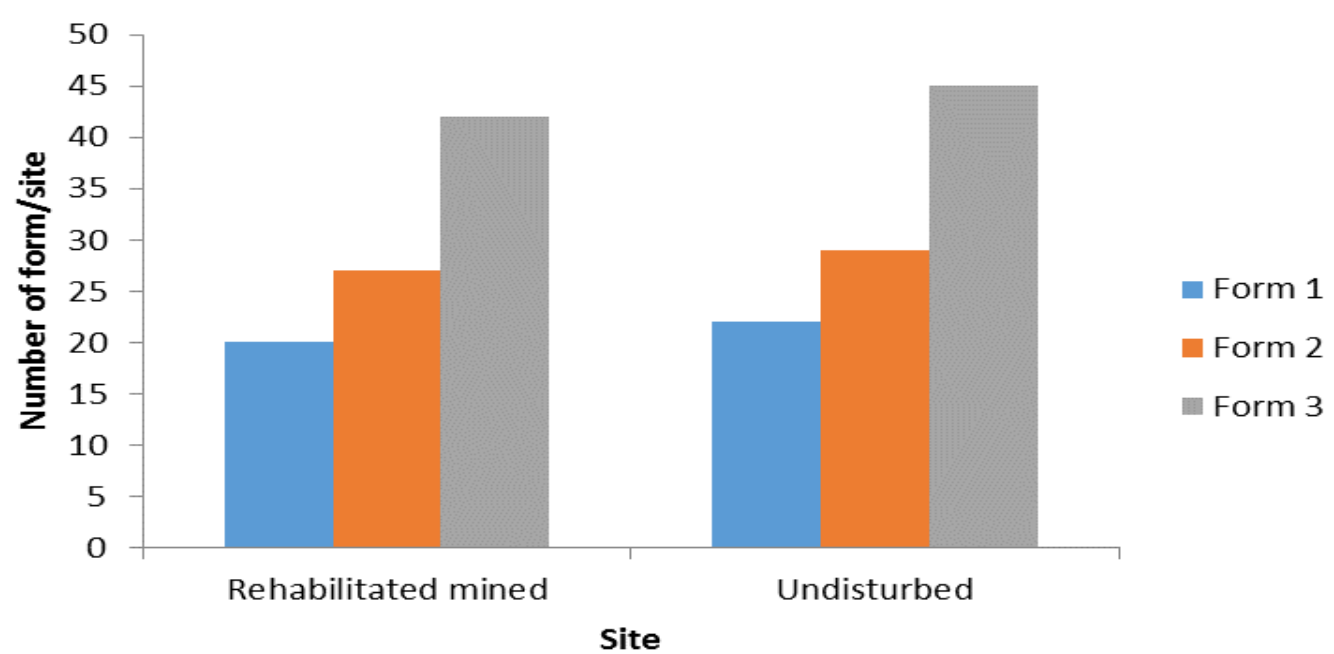

Fig. 2: Distribution of Tree Form in Both Rehabilitated Mined and Undisturbed Site. 

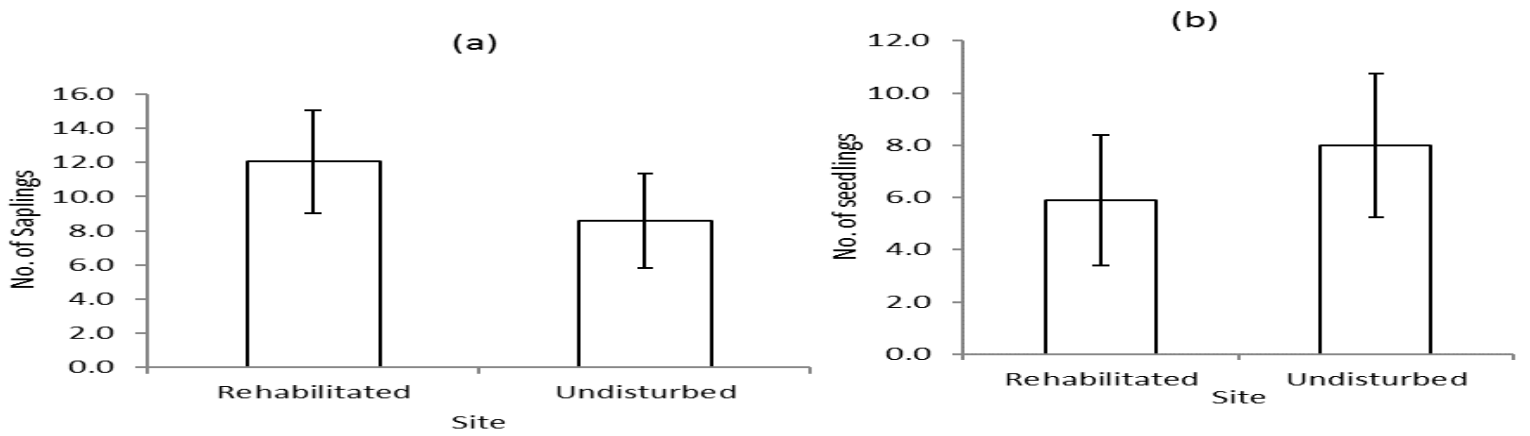

Fig. 3: The Mean Distribution of Seedlings in Both the Rehabilitated Mined and the Undisturbed Sites.

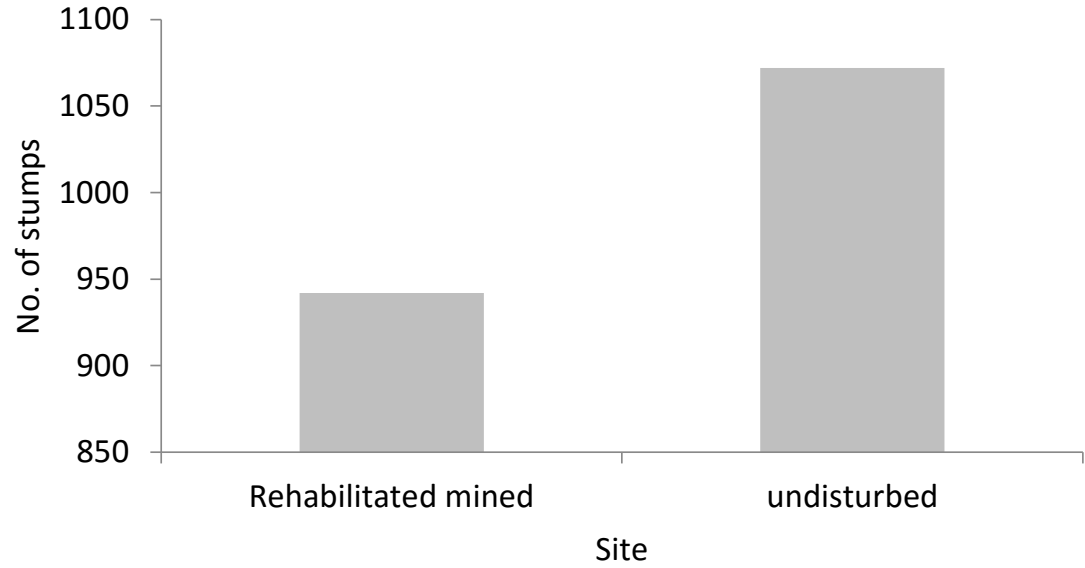

Fig. 4: Number of Stumps in both Rehabilitated and Undisturbed Sites.
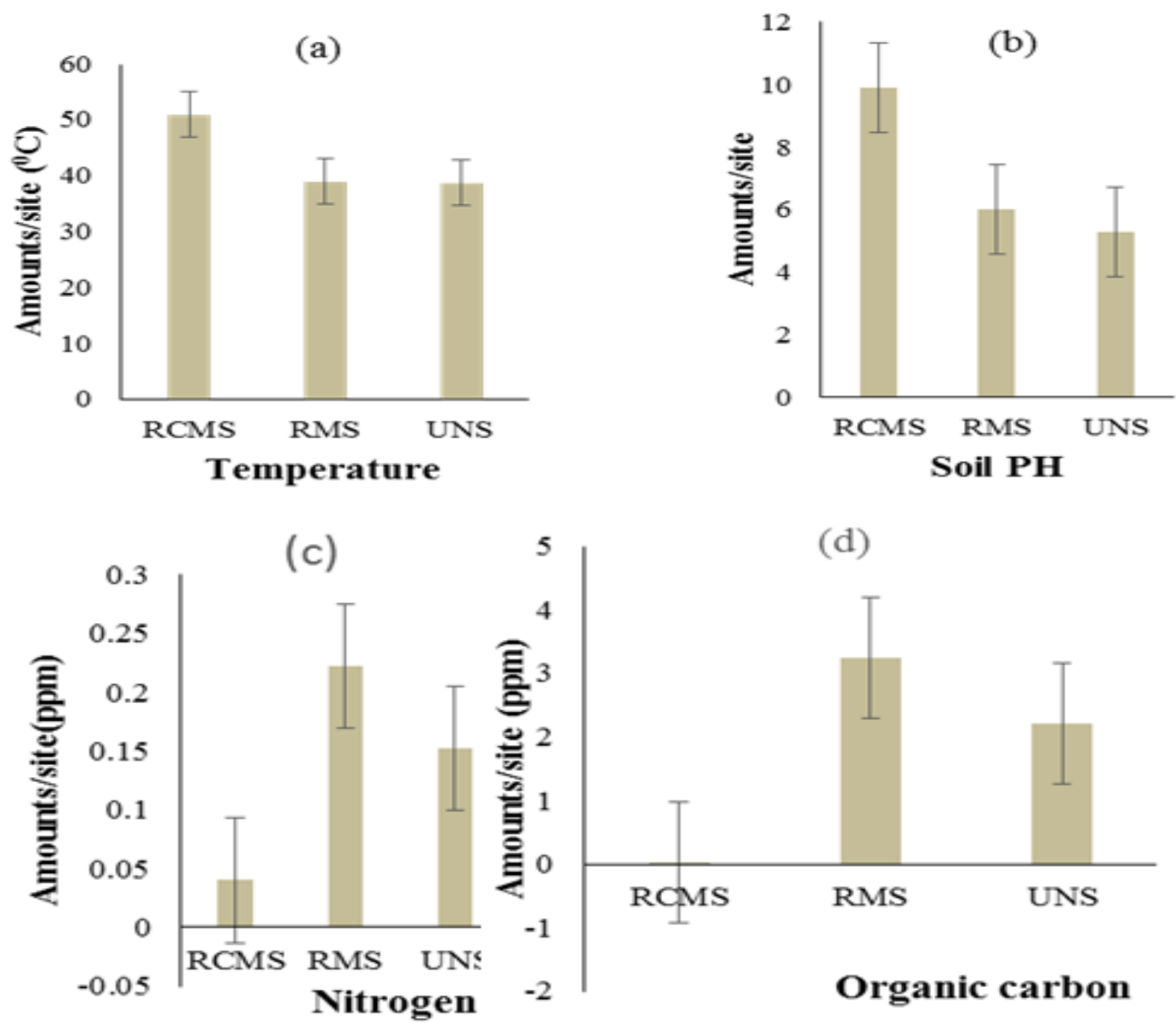

(d)

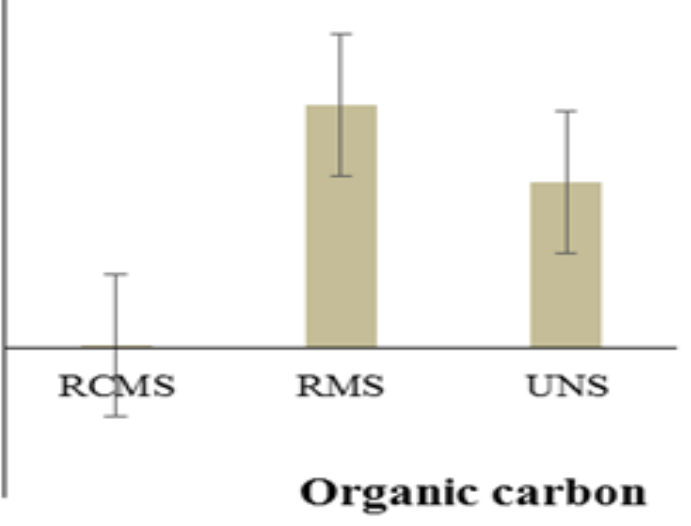



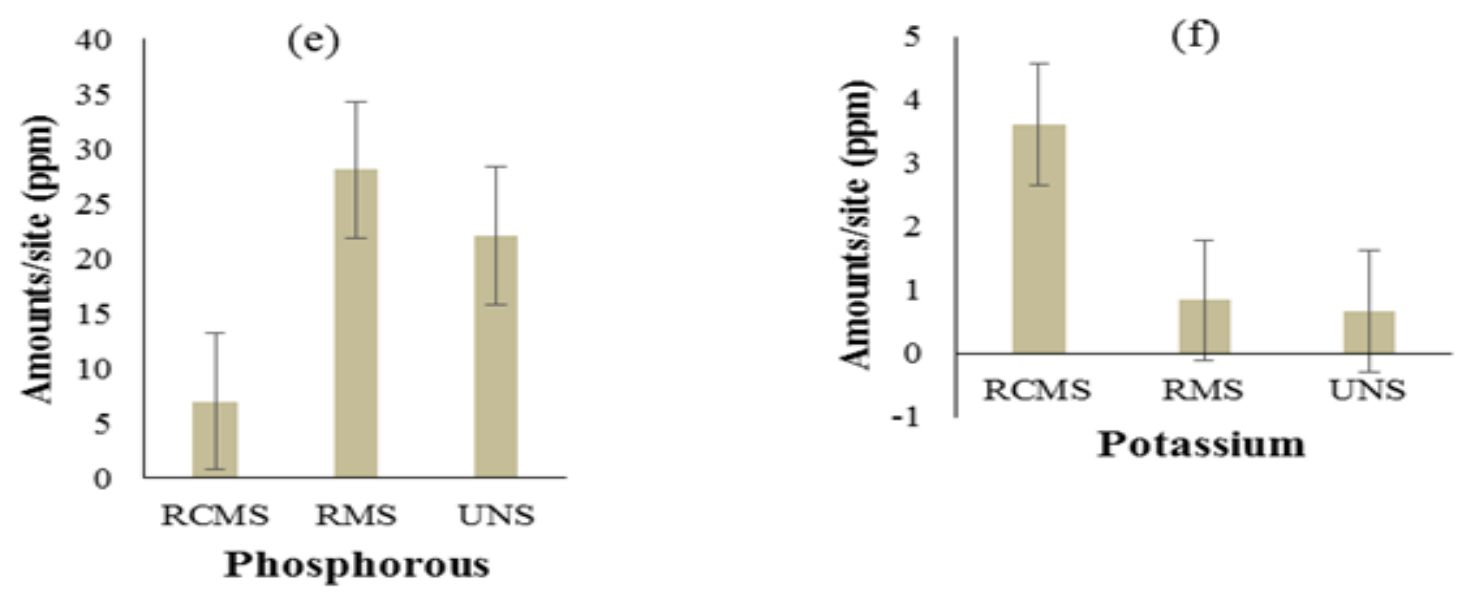

Phosphorous

(g)

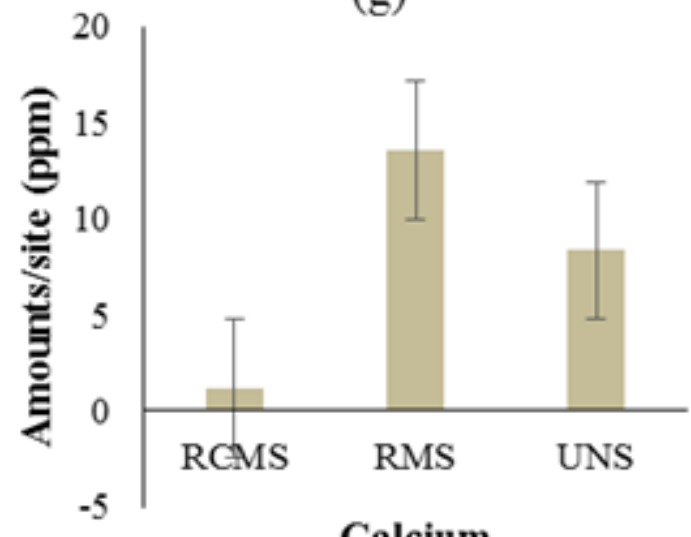

(h)
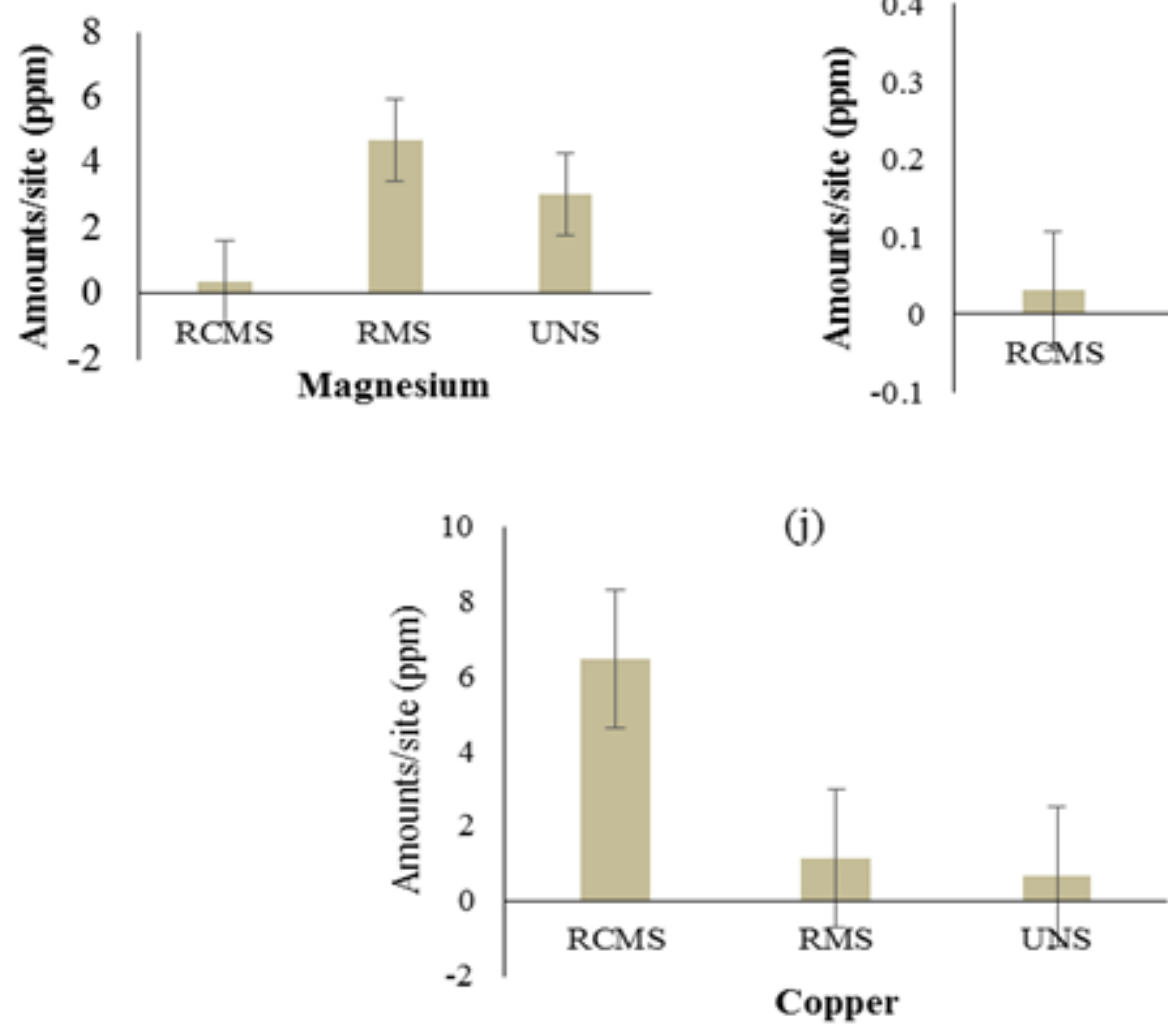

(i)

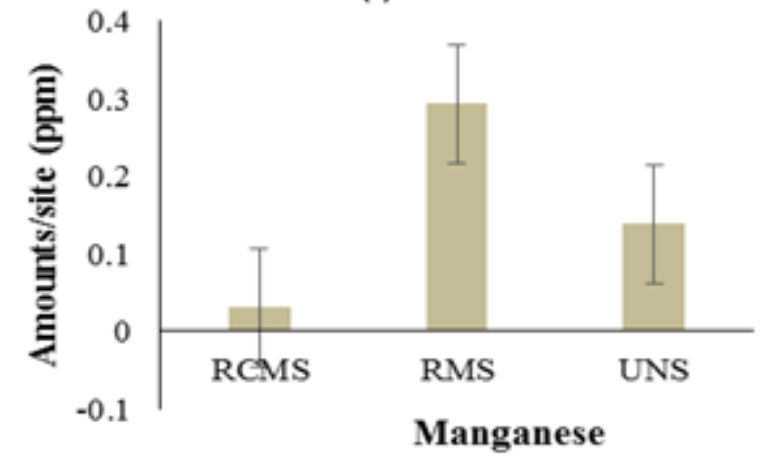



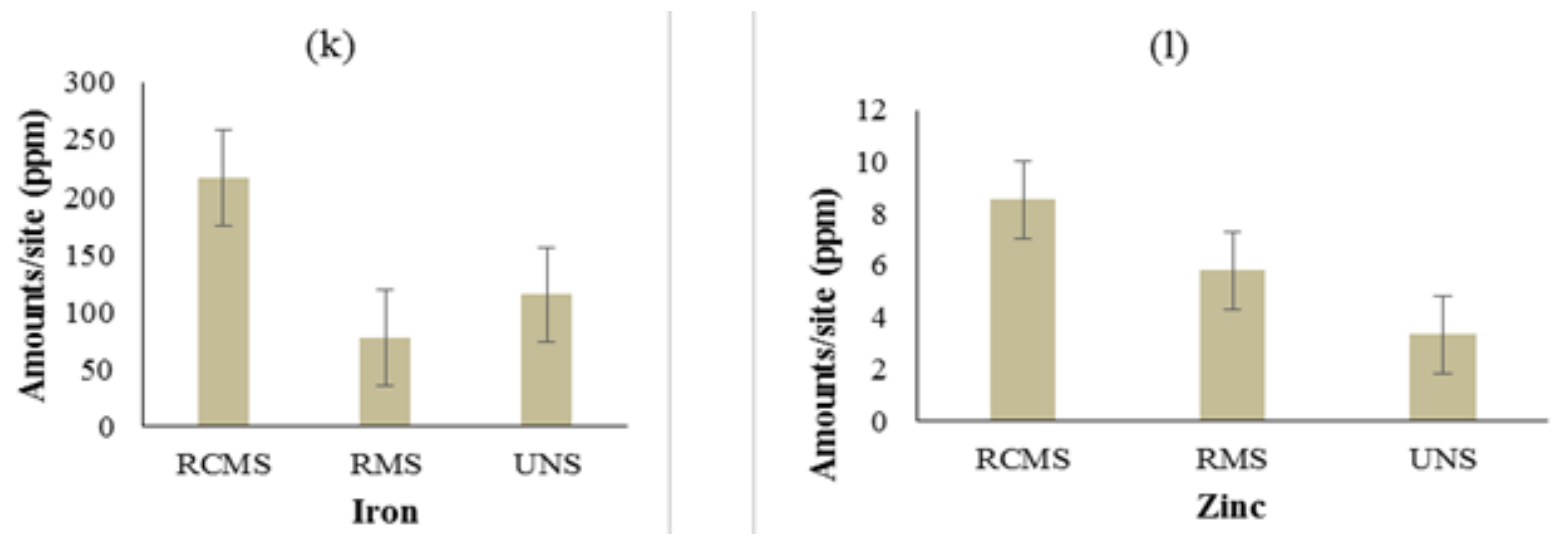

(m)

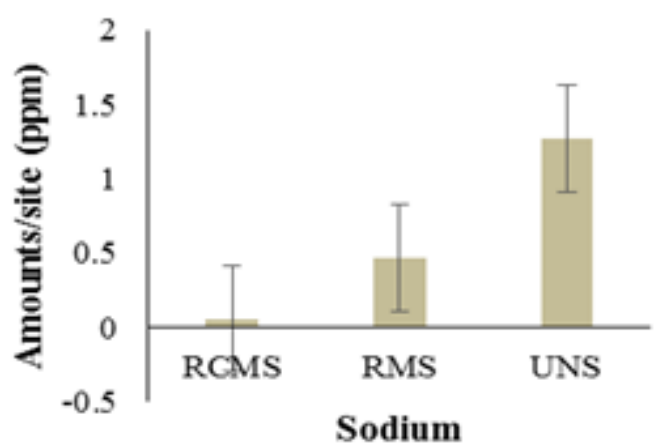

Fig. 5: Mean ( \pm S.E) Soil Characteristics Per 0.4m2/Ha Between the Three Sites of the Study: (A)Temp 0C (B)Soil Ph (C) Total Nitrogen (D)Organic Carbon(E) Phosphorous (F)Potassium (G)Calcium (H)Magnesium (I)Manganese (J)Copper (K)Iron (L)Zinc (M)Sodium. RCMS=Recently Mined RMS=Rehabilitated Mined UNS=Undisturbed Site

\section{Discussion}

\subsection{Characterizing woody vegetation}

Acacia tortilis was found to be the dominant species in both rehabilitated mined and the undisturbed site respectively. This is attributed to its tolerance to prolonged drought and poor soils. Balanites aegyptica also had a high frequency due to its importance to the indigenous community in Kerio Valley-leaves are used as fodder, stem for construction, fruits for human consumption and as animal feed during droughts with its bark and roots used for medicinal purposes. Kellman (1979) links soil properties, predation by understory animals and disturbance history to vegetation characteristics.

Exotic tree species in rehabilitation has resulted in a shift in vegetation dynamics leading to colonization of an area which results in loss of indigenous trees (Mengich, 2013). This is evident in the rehabilitated mined site in our study area which seems to be undergoing succession as evidenced by existence of Lantana camara non-woody shrub. White (1985) defines disturbance as a relatively discrete event disrupting community ecosystem or structure of the population and changes the resource availability or the physical environment. Seedlings had a low frequency in the rehabilitated mined site due to canopy cover as a result of Lantana camara, this inhibits the growth of the juveniles whereas saplings had a high frequency, which might have resulted in earlier growth before the dominance by the invasive species while in the undisturbed site the number of seedlings had a high frequency due to favorable canopy to allow seedlings growth. The saplings however recorded a low frequency as compared to rehabilitated mined site due to these sites being accessible to human disturbance. The saplings are cut to be used as fittos for construction.

Stand structure (basal area, DBH and tree height) is a reliable indicator of forest development Ludwig (2001). Undisturbed site had the lowest basal area with total number of stumps being the highest due to its accessibility, whereas rehabilitated mined site recorded the highest basal area and with less number of cut stumps. The rehabilitated mined area is under the protection of the Kenya Flourspar Company thus the low number of stumps. The site is also characterized by rich nutrient soils as a result of high organic matter from decomposition of the leaves of Lantana camara and soil deposits from the farms uphill as compared to undisturbed sites that have compacted soils. Other factors may be attributed to habitat alteration and inadequate legislation (UNEP, 2009).

\subsection{Form quality characteristics}

According to Mengich, (2013), environmental conditions, species composition and anthropogenic pressure are factors that the quality of poles is dependent on. Both sites (rehabilitated and undisturbed) had the least densities of Form 1 poles due to human impacts while Form 3 had the highest density. This explains the existence of selective extraction of quality poles compromising the long term quality of the woody vegetation. The absence of high quality (Form 1) of Terminalia brownii in both sites is as a result of its preference for posts for construction due to its durability and charcoal burning.

Kokwaro (1985) points out that the preferred size classes for construction poles range between $8 \mathrm{~cm}$ to $13 \mathrm{~cm}$. This explains why Form 3 had a high density as compared to Form 2 and 1. High stand density for low diameter classes $(\leq 7 \mathrm{~cm})$ in a forest leads to a high C.I values (Kipkiror et al., 2003). This explains the high C.I values of 50 and 22 in undisturbed and rehabilitated mined sites respectively. However this scenario was more evident in the undisturbed site which is easily accessible by human thus compromising on diameters. Forest size classes assume the inverted Jcurve common for natural forests that portray attributes of uneven ages (Leak, 1965). This again may be attributed to the economic value and wood quality of pole size classes which is low, thus multiple harvesting of wood should be harmonized and stem density per class be reduced to avoid these indiscretions (Towett, 2003). 


\subsection{Comparison of wood vegetation diversity between rehabilitated and undisturbed sites}

Woody vegetation diversity was significantly high in undisturbed site as compared to rehabilitated site. This can be attributed to a number of factors ranging from land use or disturbance, soil characteristics and vegetation characteristics i.e. abiotic and biotic factors. Biotically generated stress occur in favorable environments where a variety of species can grow well but the most dominant species eliminates the entire population of less competitive population by limiting important resources like light (Huston and DeAngelis, 1994). Rehabilitated mined site had a diversity index of 0.86 as compared to 0.93 in undisturbed site. Domination of rehabilitated site by Lantana camara generates biotic stress. This situation has hindered woody vegetation from growing due to poor light penetration an essential element for regeneration.

The continuous increase of environmental destructions (mining and deforestation) makes it hard for woody vegetation diversity to attain its standard of existence (Sax et al. (2002). Anthropogenic activities such as mining and woody vegetation harvesting for domestic uses result in a paradigm shift in woody vegetation diversity in Kerio valley. However Riha et al. (1986) states that beneath a woody vegetation cover, heterogeneity of soil results in both spatial and temporal effects of vegetation. Mining changes the soil nutrient characteristics; this however is attributed to less diverse woody vegetation in rehabilitated mined site. Though undisturbed site was highly diverse than rehabilitated mined there was no significant difference. This can be attributed to soil fertility in the undisturbed site and its accessibility by human beings who exploit the woody vegetation for domestic use. The rehabilitated area is under the protection of Kenya Flourspar Company and thus minimal number of stumps as compared to undisturbed site.

\subsection{Soil characteristics}

Mining has significant effects on soil chemical properties. In this study, soils from rehabilitated mined site contained significantly higher organic matter compared to the other two sites. Rehabilitated mined site is dominated by lantana camara providing soil fertility through leaf foliage in contrast with undisturbed site which had no vegetation beneath the woody vegetation and recently mined site had no vegetation. This result compares favorably with studies done by Emadi et al., 2008; FAO, 2004). Various studies have examined the effects of land use on physio-chemical properties of soil (Emadi et al., 2008). With absence of vegetation, the soil is deprived of organic matter which is the key to soil fertility and productivity especially in ASALS (FAO. 2004), and is highly exposed to agents of soil erosion. Organic carbon is a sensitive quality indicator suggesting that within a narrow range of soil, it may serve as a suitable indicator of soil quality among other soil properties (Murage et al., 2000). Once vegetation cover is restored, it improves the soil structure, soil water balance, chemical soil fertility and restores soil biodiversity and ecosystem services through reduced soil erosion (Mekuria et al., 2007). Soil organic matter may offer an insight into soil fertility changes and the sustainability of past management history (Kapkiyai et al., 1998).

Land use plays an important role in soil nutrient accumulation and losses (Fu et al., 2000). In addition to protecting soil from erosion agents, the tree canopy-herbaceous layer interaction improves soil fertility through addition of nitrogen and organic matter, the vegetation supplies plant litter which decomposes to supply the soils organic carbon pools (Kellman, 1979). Recently mined site had significantly high soil $\mathrm{pH}$, zinc, copper, iron and potassium while manganese, sodium, magnesium, calcium, phosphorus and nitrogen were significantly low. This result can be explained by effects of mining on soil. The top fertile soils are buried deep while the inner infertile soils are exposed to the surface. Vegetation is removed destabilizing soil nutrient and even decomposers. Moreover, woody vegetation depletion of base cations effects on soil $\mathrm{pH}$ and nutrients can be attributed to a high amount of some nutrients in sites (Challinor 1968).
Phosphorous however is an essential nutrient for woody vegetation growth hence its uptake by plants and subsequent removal through mining is attributed to acidifying effect on soil. This explains why soils from rehabilitated mining were the most acidic.

\section{Conclusion and recommendations}

The findings of this study indicate that mining has an effect on woody vegetation. Woody vegetation composition in Kerio valley varied differently between the rehabilitated mined site and the undisturbed site. This variation is controlled by environmental setting, land use changes, accessibility of woody vegetation and local knowledge on uses of woody vegetation. However, woody vegetation diversity was not significantly different between the two sites. This is due to accessibility of the undisturbed mined site, the vegetation cover, site elevation and soil nutrient characteristics.

Form quality characteristics between the two sites (rehabilitated and undisturbed) does not differ. Both had the least densities of Form 1 poles due to human impacts while Form 3 had the highest density. Existence of selective extraction of quality poles compromises the long term quality of woody vegetation. However, colonization of the rehabilitated mined area by Lantana camara has had devastating effects on regeneration of woody vegetation hindering light essential for woody vegetation seedlings and saplings growth. Restoration of vegetation improves soil structure, soil water balance, chemical soil fertility and restores soil biodiversity and ecosystem services through reduced soil erosion. Heterogeneity of soil results in both spatial and temporal effects of vegetation. Land use plays an important role in soil nutrient accumulation and losses (Fu et al., 2000).

Protecting soil from erosion agents, the tree canopy-herbaceous layer interaction improves soil fertility through addition of nitrogen and organic matter, the vegetation supplies plant litter which decomposes to supply the soils organic carbon pools (Kellman, 1979). Lantana camara has assisted in enrichment of soil nutrients and prevention of soil erosion. Soil characteristics differed significantly between the two sites. This is as a result of land topography, where rehabilitated mined site seems to be flat whereas most parts of the undisturbed sites is slant and raised. The underground vegetation cover is bare in undisturbed site thus prone to erosion while rehabilitated mined site is covered by Lantana camara curbing soil erosion.

\section{Acknowledgements}

We acknowledge the financial support from Egerton University on "Msc Dryland scholarship" under the Division of research and extension. Robert Kipruto and Koskei Alfayo conducted data collection.

\section{References}

[1] Challinor, A., Wheeler, T., Garforth, C., Craufurd, P.,Kassam, A.,2007. Assessing the vulnerability of food crop systems in Africa to climate change. Climatic Change 83, 381-399 http://dx.doi.org/10.1007/s10584-007-9249-0.

[2] Emadi, M., Emadi, M., Baghernejad, M., Fathi, H. \& Saffari, M (2008). Effect of Land Use Change on Selected Soil Physical and Chemical Properties in North Highlands of Iran. Journal of Ap$\begin{array}{lll}\text { plied } & \text { Sciences. } & \text { 8, }\end{array}$ http://dx.doi.org/10.3923/jas.2008.496.502.

[3] FAO, U. (2004). UNEP. 1994. Land degradation in south Asia: Its severity, causes and effects upon the people. World Soil Resources Report (78).

[4] FAO. (2004). Carbon Sequestration in Dryland Soil. World Soil Resources Report Series.

[5] Ghose, M. K., R. Paul and S. K. Banerjee (2004). Assessment of the impacts of vehicular emissions on urban air quality and its management in Indian context: the case of Kolkata (Calcutta). Envi- 
ronmental Science \& Policy 7(4): 345-351. http://dx.doi.org/10.1016/j.envsci.2004.05.004.

[6] GOK (2009). Survey on Population Census for Demographic and Development Agenda. 267-269.

[7] Hancock, G. R., M. K. Grabham, P. Martin, K. G. Evans and A Bollhafer (2006). A methodology for the assessment of rehabilitation success of post mining landscapesa sediment and radionuclide transport at the former Nabarlek uranium mine, Northern Territory, Australia. Science of the Total Environment 354(23): 103-119. http://dx.doi.org/10.1016/j.scitotenv.2005.01.039.

[8] Huston, M. A. and D. L. DeAngelis (1994). Competition and coexistence: the effects of resource transport and supply rates. American Naturalist: 954-977. http://dx.doi.org/10.1086/285720.

[9] Jeffries, P., S. Gianinazzi, S. Perotto, K. Turnau and J.-M. Barea (2003). The contribution of arbuscular mycorrhizal fungi in sustainable maintenance of plant health and soil fertility. Biology and fertility of soils 37(1): 1-16.

[10] Kapkiyai, J., Woomer, P.L., Qureshi, J., Smithson, P. and Karanja, N. 1999. Soil organic matter and nutrient dynamics in a Kentan nitisol under long-term fertilizer and organic input management. Soil Biology and Biochemistry 31:1173-1782. http://dx.doi.org/10.1016/S00380717(99)00088-7.

[11] Kellman (1979). Soil Enrichmnet by Neo-Tropical Savvanah Trees. Ecology 67: 565-577.

[12] Kigomo, B. (2003). Forests and woodlands degradation in dryland Africa: A case for urgent global attention. XII World Forestry Congress, Quebec, Canada.

[13] Kipkiror, L. J. and J. Towett (2003). Towards Ensuring a Supply of Sufficient and Quality Water in the Lagam Escarpment and the Kerio Valley in Marakwet District, Kenya.

[14] Kokwaro, J, O., 1985. The distribution and economic importance of the mangrove forests in Kenya. J.E Afr.Nat.Hist.Soc.75:1-12.

[15] Leak, W.B. 1964. An expression of diameter distribution for unbalanced, uneven-aged stands and forests. For. Sci. 10: 39-50.

[16] Ludwig F (2001) Tree-grass interactions on an East AfricanSavanna. The effects of competition, facilitation and hydraulic lift. Tropical Resource Management Series 39. Wageningen University, Wageningen.

[17] Maitima (2009). The Linkages between Land use change, Land degradation and Biodiversity across East Africa.

[18] Mekuria, W., E. Veldkamp, M. Haile, J. Nyssen, B. Muys and K. Gebrehiwot (2007). Effectiveness of exclosures to restore degraded soils as a result of overgrazing in Tigray, Ethiopia. Journal of Arid Environments 69(2): 270-284. http://dx.doi.org/10.1016/j.jaridenv.2006.10.009.

[19] Mengich (2013). Composition and distribution of indigenous trees and shrubs as possible criteria for indicating adapted species in semi-arid rangelands. Ecology.

[20] Murage, E.W, P.L., Karanja, N.K. and Woomer. 2001. Estimating tota system $\mathrm{C}$ in smallhold farming systems of the East Africa Highlands. Assessment Methods for Soil Carbon (R. Lal, J.M. Kimble, R.F. Follett and B.A. Stewart, eds.), Advances in Soil Science (series). Lewis Publishers, Boca Raton, USA. pp. 147-166.

[21] Nangulu (2001). Food Security and Coping Mechanisms in Kenya's Marginal Areas: The Case of West Pokot, West Virginia University Libraries.

[22] Newton, A.C., Hill, R.A., Echeverrı'a, C., Golicher, D., Rey Benayas, J.M.,Cayuela, L. \& Hinsley, S. (2009) Remote sensing and the future of landscape ecology.Progress in Physical Geography,33, 528-546. http://dx.doi.org/10.1177/0309133309346882.

[23] Omambia, A. N., C. Shemsanga and Y. Li (2009). Combating climate change in Kenya: efforts, challenges and opportunities. Rep. Opin 1: 65-76.

[24] Parsons, T. R. Maitay. \& Lalli, CM 1984. A manual of chemica and biological methods for seawater analysis, Oxford, Pergamon Press, 173p.

[25] Riha S J, James BR, Senesac GP and Pallent E (1986) Spatial variability of soil $\mathrm{pH}$ and organic matter in forest plantations. Soil Sci Soc Am J 50:1347-135. http://dx.doi.org/10.2136/sssaj1986.03615995005000050053x.

[26] Sax, D. F., S. D. Gaines and J. H. Brown (2002). Species invasion exceed extinctions on islands worldwide: a comparative study of plants and birds. The American Naturalist 160(6): 766-783. http://dx.doi.org/10.1086/343877.

[27] Thom (1983). Ecology and production in Baringo-Kerio valley, Kenya." Geographical Review: 15-29.

[28] UNEP (2006). Land degradation in world deserts. 4: 1-4.

[29] White F 1983 Chapter XII. The Lake Victoria Regional Mosaic. In: The Vegetation of Africa. UNESCO, Paris. P 179-184. 